Journal of Animal and Veterinary Advances 10 (4): 495-501, 2011

ISSN: $1680-5593$

(C) Medwell Journals, 2011

\title{
Molecular Characteristics of Porcine SIMI Gene and its Variants Association with Carcass and Meat Quality Traits
}

\author{
${ }^{1}$ Zhe Chen, ${ }^{2}$ Xiaofeng Zhao, ${ }^{1}$ Zhu Hao, ${ }^{1}$ Xiaoling Jiang, ${ }^{1}$ Xiaoling Guo and ${ }^{1}$ Ningying $\mathrm{Xu}$ \\ ${ }^{1}$ College of Animal Sciences, Zhejiang University, Hangzhou, China \\ ${ }^{2}$ College of Life and Environmental Sciences, Zhejiang Normal University, Hangzhou, China
}

\begin{abstract}
In the present study, the cDNA sequence of porcine SIM1 gene was cloned by homology cloning and rapid amplification of cDNA ends approach. The full length cDNA of SIM1 consists of 3720 bp nucleotides. It contains an Open Reading Fame (ORF) of 2301 bp which encodes a corresponding protein of 766 amino acid residues and flanked by $461 \mathrm{bp} 5$ ' UTR and $958 \mathrm{bp}$ 3' UTR. The porcine SIM1 protein has a high homology to that of human and cattle. Expression analysis revealed an ubiquitous distribution in all examined tissues. Two novel single nucleotide polymorphisms (SNPs) $\mathrm{c}+534 \mathrm{~T}>\mathrm{C}$ and $\mathrm{c}+1677 \mathrm{C}>\mathrm{T}$ were found. Association analysis between SNPs and carcass and meat quality traits were carried out in a Pietrain $\mathrm{x}$ Jinhua F2 population $(\mathrm{n}=294)$. The results revealed extremely significant effect on average backfat thickness, intramuscular fat content, intramuscular water content, ham temperature, ham fat weight and ham lean weight $(p<0.01)$ along with significant effect on loin eye area and ham $\mathrm{pH}(\mathrm{p}<0.05)$.
\end{abstract}

Key words: $S I M 1$ gene, cDNA, expression, SNPs, carcass, meat quality traits, China

\section{INTRODUCTION}

The SIM1 gene is a basic Helix-Loop-Helix/PerArnt-SIM (bHLH-PAS) transcription factor which is essential for the terminal differentiation of the hypothalamic neurons and strongly expressed during development of the hypothalamic-pituitary axis in the Paraventricular Nucleus (PVN) (Michaud et al., 1998). The hypothalamus integrates a variety of signals from brain and the periphery which have profound affects on a range of behavioral and homeostatic processes. Thus, alteration in hypothalamic function may lead to disorders ranging from autism, obesity and Prader-Willi Syndrome (PWS) to endocrine disorders (Swaab et al., 1995; Insel et al., 1999; Hollander et al., 2003).

SIM1 mutations are one of the few known causes of nonsyndromic monogenic obesity in both humans and mice (Tolson et al., 2010). Several chromosomal deletions and a balanced translocation involving chromosome 6q16-6q21 which encompasses the SIM1 locus have been identified in patients with monogenic severe obesity (Gilhuis et al., 2000; Varela et al., 2006).

Heterozygous SIM1-knockout mice developed hyperphagic with increased linear growth and enhanced sensitivity to diet-induced obesity (Michaud et al., 2001; Holder et al., 2004) while mice overexpressing SIM1 partially rescues agouti yellow and diet-induced obesity by normalizing food intake (Kublaoui et al., 2006). In the past decades, many candidate gene mutations had been found to be associated with carcass and meat quality traits such as backfat thickness, intramuscular fat content and meat color (Liu et al., 2009; Kobayashi et al., 2009). Thus as a selection tool, DNA test was widely used in pig industry for improvement of pork quality (Visscher et al., 2000). However, litter research has been performed to conducted the genetic role of SIM1 gene on carcass and meat quality.

Porcine SIM1 gene had been mapped at chromosome $1 \mathrm{p} 13$ and a C/T mutation in exon 8 had been found. Association analysis showed that this SNP had significant effect on growth, carcass composition and meat quality (Zhao et al., 2008). Based on the biology role of SIM1 in energy balance and the genetic studies in human and mouse, the SIM1 gene was considered to be a promising candidate gene for carcass and meat quality traits.

The aims of current study are characterizing cDNA sequence of porcine SIM1 gene and detecting novel Single Nucleotide Polymorphisms (SNPs) in the coding region. We further investigated the relationship between SNPs and recorded traits using a Pietrain $\mathrm{x}$ Jinhua F2 population.

Corresponding Author: Ningying Xu, College of Animal Sciences, Zhejiang University, Kaixuan Road 268, Hangzhou, 310029 Zhejiang, China 


\section{MATERIALS AND METHODS}

Tissue collection and RNA extraction: Preliminary detection for cDNA sequence and polymorphisms of SIM1 gene was carried out in 5 Jinhua and 5 Pietrain pigs (20 days old). Tissue samples including stomach, spleen, pancreas, heart, lung, kidney, thyroid gland, muscle, liver and hypothalamus were removed, immediately frozen in liquid nitrogen and stored at $-80^{\circ} \mathrm{C}$. Total RNA was extracted using the Trizol reagent (Invitrogen, Carlsbad, CA, USA) according to the manufacture's protocol. RNA concentration was measured at $260 \mathrm{~nm}$ using the NanoDrop ND-100 spectro-photometer (NanoDrop Technologies, Wilmington, DE, USA). The total RNA was reverse transcribed into first strand cDNA by $\mathrm{M}-\mathrm{MLV}$ reverse transcriptase (Promega, USA). The cDNA were used as template in gene cloning and expression profile analysis.

Isolation of the porcine SIM1 cDNA fragment: Based on the human and mouse SIM1 mRNA sequence (GenBank, acc. nos. NC_005068 and NC_011376, respectively), primers (CDS-F, CDS-R) were designed using Oligo 6.0 to amplify porcine $S M 1$ gene cDNA fragment (Table 1). The PCR amplification was performed in a $25 \mu \mathrm{L}$ reactions containing 100-300 ng of cDNA isolated from Jinhua hypothalamus, $400 \mu \mathrm{M}$ of dNTPs (Sangon, China), $0.25 \mu \mathrm{M}$ of each primer and $1 \mathrm{U}$ of Taq polymerase (TaKaRa, Japan).

The PCR procedure consisted of an initial denaturation at $94^{\circ} \mathrm{C}$ for $5 \mathrm{~min}$ followed by 36 cycles of $94^{\circ} \mathrm{C}$ for $30 \mathrm{sec}, 55^{\circ} \mathrm{C}$ for $30 \mathrm{sec}$ and $72^{\circ} \mathrm{C}$ for $30 \mathrm{sec}$ with a final extension at $72^{\circ} \mathrm{C}$ for $10 \mathrm{~min}$. The products were excised and purified after electrophoresis on a $1.5 \%$ EtBr gel using a AxyPrep ${ }^{\mathrm{TM}}$ DNA Gel Extraction Kit (Axygen Scienrific, CA, USA). The PCR purified products were ligated into the pGEM-T easy vector system (TaKaRa, Japan) and then transformed into competent $E$. coil DH5 $\alpha$ cell. Plasmid DNA was purified and sequenced in Invitrogen Trading company (Shanghai, China) using an automated ABI3730 analyzer (Applied Biosystems, CA, USA).

Rapid amplification of 3 ' and 5' cDNA ends: GeneSpecific Primers (GSP) and Nested Gene-Specific Primers (NGSP) were designed based on the obtained cDNA fragment. 5'-RACE reactions were performed using SMARTer ${ }^{\mathrm{TM}}$ RACE cDNA Amplification Kit (Clontech Laboratories, CA, USA). Total RNA were reverse transcribed with SMARTer $\alpha$ A oligo into RACE-Ready cDNA. GSP1 and 10× Universal Primer A Mix (UPM) were used for 5'-RACE. The PCR was performed using the following condition: 5 cycles with $94^{\circ} \mathrm{C}$ for $30 \mathrm{sec}, 72^{\circ} \mathrm{C}$ for $30 \mathrm{sec}$ then 5 cycles with $94^{\circ} \mathrm{C}$ for $30 \mathrm{sec}, 70^{\circ} \mathrm{C}$ for 30 and $72^{\circ} \mathrm{C}$ for $2 \mathrm{~min}$ at last 25 cycles with $94^{\circ} \mathrm{C}$ for $30 \mathrm{sec}, 68^{\circ} \mathrm{C}$ for 30 and $72^{\circ} \mathrm{C}$ for $2 \mathrm{~min}$.

3'-RACE experiments were carried out with 3'-Full RACE Core Set (TaKaRa, Japan) according to the manufacture's protocol. About $4 \mu \mathrm{g}$ of total RNA isolated from hypothalamous was reverse transcribed into first-strand cDNA using the adaptor primer. 3'-RACE OUTER primer and GSP2 were used for outer PCR, 3'-RACE INNER Primer and NGSP2 were used for nested PCR. 3'-RACE PCR profile were $94^{\circ} \mathrm{C}$ for $3 \mathrm{~min}$, followed by 20 cycles for GSP 2 or 30 cycles for NGSP 2 with denaturation at $94^{\circ} \mathrm{C}$ for $30 \mathrm{sec}$, annealing at $55^{\circ} \mathrm{C}$ for $30 \mathrm{sec}, 1 \mathrm{~min}$ at $72^{\circ} \mathrm{C}$ and a final extension of $10 \mathrm{~min}$ at $72^{\circ} \mathrm{C}$. 3'-RACE and 5'-RACE PCR products were gel-purified and sequenced as mentioned above.

Sequence analysis: The Open Reading Frame (ORF) was found using the DNA star software and the nucleotide

\begin{tabular}{|c|c|c|c|}
\hline Primer names & Primer sequence $\left(5^{\prime}-3^{\prime}\right)$ & Function & $\mathrm{T}_{m}\left({ }^{\circ} \mathrm{C}\right)$ \\
\hline CDS-F & TTTTCTGGTCGCCGAGTT & cDNA fragment & 62 \\
\hline CDS-R & TGGAGGCTGCTGGTAGTTTG & & \\
\hline GSP1 & CATGGTGAAGTGTTGGCAAGA & & 68 \\
\hline \multirow[t]{2}{*}{ UPM } & CTAATACGACTCACTATAGGGC & & \\
\hline & AAGCAGTGGTA 5'-RACE TCAACGCAGAGT & & \\
\hline GSP2 & GATCCACGGGCGAGGTCATT & 3'-RACE outer PCR & 55 \\
\hline OUTER & TACCGTCGTTCCACTAGTGATTT & & \\
\hline NGSP2 & CCGAGCAGTATCAAAGTAGCCC & 3'-RACE inner PCR & 55 \\
\hline INNER & CGCGGATCCTCCACTAGTGATTTCACTATAGG & & \\
\hline EX-F & TGAAGATCCGACAGTACAG & RT-PCR & 60 \\
\hline EX-R & GGAGTCCAGGAAGATGAG & & \\
\hline$\beta$-actin-F & GCAAGTACTCTGTCTGGATTG & sqRT-PCR & 60 \\
\hline$\beta$-actin-R & TTTGCGGTGGACAATGGA & & \\
\hline SIM1-1F & GCCCTACCACTCTCACTT & Detection for C534T & 55 \\
\hline SIM1-1R & CTTCTTGTCCTGCCTCCT & & \\
\hline SIM1-2F & TGGGATGAAGATAGTGTGG & Detection for $\mathrm{T} 1677 \mathrm{C}$ & 55 \\
\hline SIM1-2R & AAGTGTTGGCAAGAGCAG & & \\
\hline
\end{tabular}


sequences were translated into amino acids by the DNAMAN program. Phylogenetic and molecular evolutionary analysis were conducted using MEGA 3.1 (Kumar et al., 2004). Homologous of SIM1 proteins among different species were analyzed by DNA star software.

Tissue expression: The expressions of SIM1 gene were detected by using semi-quantitative RT-PCR method with $\alpha$-actin gene as endogenous control, the SIM1 gene-specific primers (EX-F, EX-R) were designed based on the obtained cDNA sequence (Table 1). RT-PCR profile was denaturation at $94^{\circ} \mathrm{C}$ for $3 \mathrm{~min}, 40$ cycles at $94^{\circ} \mathrm{C}$ for $30 \mathrm{sec}$, annealing at $60^{\circ} \mathrm{C}$ for $30 \mathrm{sec}$ and extension at $72^{\circ} \mathrm{C}$ for $1 \mathrm{~min}$ and last extension at $72^{\circ} \mathrm{C}$ for $10 \mathrm{~min}$. The PCR products were electrophoresis on a $1.5 \%$ $\mathrm{EtBr}$ gels and photographed under UV light using a Biocapt (Vilber Lourmat, France) and optical density values were analyzed using Bio-Profil Bio-2D software.

Reference population and date collection: To assess the effect of SIM1 variants on carcass and meat quality traits, the F2 resource population was constructed by the Pietrain and Jinhua pigs (PJF2) which including 4F1 boars and $10 \mathrm{~F} 1$ sows and $306 \mathrm{~F} 2$ progeny. All $306 \mathrm{~F} 2$ offspring were used in the experiment, PJF2 animals were raised under normal conditions, slaughtered following electric shock at 217 days of age ( $\mathrm{SD}=30.9$ days, live weight $81.3 \pm 10.55 \mathrm{~kg}$ ) at commercial abattoir.

Four carcass traits, including: average backfat thickness (at four locations on the left carcass), loin eye area, ham fat weight, ham lean weight, along with six meat quality traits, including: intramuscular fat, protein, water content, water holding capacity, ham temperature and $\mathrm{pH}$ were recorded according to previous description (Zhao et al., 2008).

Amplification and SSCP analysis: Two novel SNPs and one previously reported SNP were found by alignment of PCR products of Jinhua and Pietrain pigs. Based on the porcine SIM1 CDNA sequence and human SIM1 genomic DNA sequence (GenBank accession no. NC_000006), two pairs of primers were designed to amplify the novel mutations (Table 1). The PCR program included: denaturation at $94^{\circ} \mathrm{C}$ for $5 \mathrm{~min}$ followed by 36 cycles of denaturation at $94^{\circ} \mathrm{C}$ for $30 \mathrm{sec}$, annealing at $60^{\circ} \mathrm{C}$ for SIM1 1 or $58^{\circ} \mathrm{C}$ for SIM1 2 for $30 \mathrm{sec}$ and extension at $72^{\circ} \mathrm{C}$ for $30 \mathrm{sec}$ with a final extension at $72^{\circ} \mathrm{C}$ for $10 \mathrm{~min}$. All amplicons were subjected to PCR-single-strand conformational polymorphism (PCR-SSCP) analysis according to Zhao et al. (2008). The samples showing anomalous migration in polyacrylamide gel were sequenced to identify the SNP mutation type.

Statistical analysis: For studying the association between SIM1 gene polymorphisms and recorded traits in the PJF2 crossbred animals were analyzed using GLM procedure (SPSS v16.0), the following model was used:

$$
\mathrm{Y}_{\mathrm{ijklm}}=\mu+\mathrm{S}_{\mathrm{i}}+\mathrm{F}_{\mathrm{j}}+\mathrm{G}_{\mathrm{k}}+\mathrm{l}_{1}+\beta * \mathrm{X}_{\mathrm{ijklm}}+\mathrm{e}_{\mathrm{ijklm}}
$$

Where:

$\mathrm{Y}_{\mathrm{ijklm}}=$ The observation of the trait

$\mu \quad=$ Population mean

$\mathrm{S}_{\mathrm{i}} \quad=$ The fixed effect of sex

$F_{j} \quad=$ The fixed effect of father

$\mathrm{G}_{\mathrm{k}}=$ The fixed effect of kth genotype

$1_{1}=$ The random effect of litter

$\beta=$ The regression coefficient of the slaughter weight

$\mathrm{X}_{\mathrm{ijklm}}=$ The slaughter weight as covariate

$\mathrm{e}_{\mathrm{ij \textrm {jlm }}}=$ The random residual error

The model for intramuscular fat content trait include the average backfat thickness as covariate instead of slaughter weight. The Least Square Means (LSM) method of the GLM (General Linear Model) procedure was used for statistical analysis.

\section{RESULTS AND DISCUSSION}

Cloning of porcine SIM1 gene: The 3720 bp porcine SIM1 cDNA sequence was obtained by splicing sequence of RT-PCR and RACE products further analysis revealed an Open Reading Frame (ORF) of 2301 bp which encoding a corresponding protein of 766 amino acid residues with a predicted molecular weight $85.3 \mathrm{kDa}$ and theoretical isolectric point of 7.29. The cDNA contained a 5' Untranslated Region (UTR) of 461 bp nucleotides and a 3' UTR of 958 bp nucleotides. 3' UTR included a TGA termination codon and one putative polyadenylation consensus signals (AATAAA) and a poly (A) tail. The obtained cDNA and amino acids sequence were then submitted to the GenBank database (GenBank, Acc. nos. GU451304 and NP_001166056, respectively).

Expression of porcine SIM1 gene in tissues: Semiquantitative RT-PCR was used to detect expression profile of porcine SIM1 gene. The electrophoresis results showed that the fragments of SIM1 gene $(176 \mathrm{bp})$ and $\beta$-actin gene (116 bp) were obtained (Fig. 1). The $\beta$-actin gene displayed a basically identical signals in all tissues. Porcine SIM1 gene showed ubiquitous distribution in all examined tissues including stomach, spleen, pancreas, heart, lung, kidney, subcutaneous fat, muscle, liver and hypothalamus while particularly higher in kidney and muscle (Fig. 1).

Molecular phylogenetic tree: The alignment of nucleotide sequence showed that porcine SIM1 shared a high 


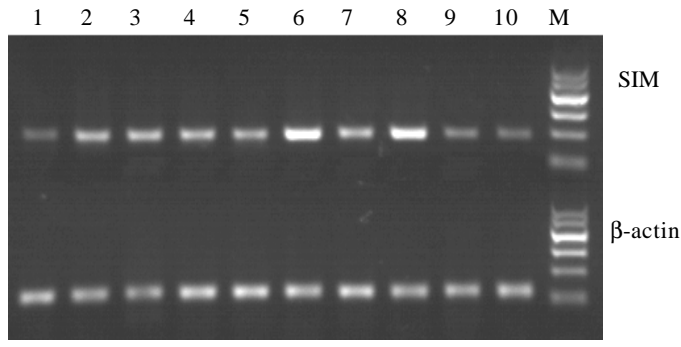

Fig. 1: Tissue expression distribution of porcine SIM1 gene. 1: stomach; 2 , spleen; 3 , pancreas; 4 , heart; 5 , lung; 6 , kidney; 7 , subcutaneous fat; 8 , muscle; 9, liver; 10, hypothalamus; M, DL600 markers, 6 bands: $100,200,300,400,500,600 \mathrm{bp}$

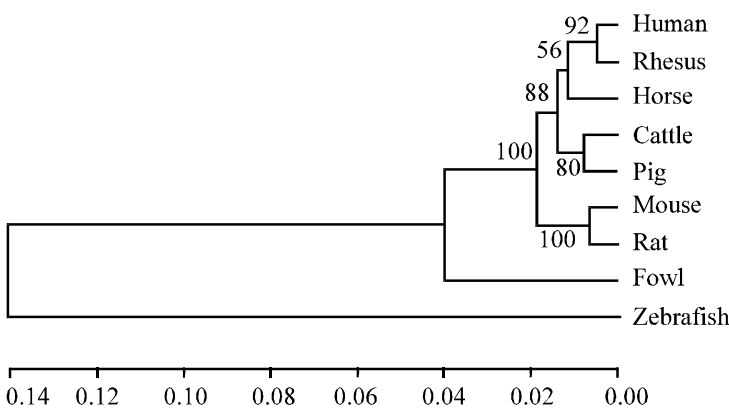

Fig. 2: The molecular phylogenetic tree of the SIM1 gene conducted by UPGMAM algorithm of MEGA 3.1, bootstrap confidence values are based on 1000 bootstrap replicates. GenBank accession numbers are: human (NP_005059), rhesus (XP_001 086054), horse (XP_001503954), cattle (XP_869704), pig (NP_001166056), Mouse (NP_035506), rat (NP_001101111), fowl (XP_419817), zebrafish (NP_835740)

identity with human $(97.9 \%)$, cattle $(96.7 \%)$, horse $(97.1 \%)$, mouse $(95.2 \%)$, rat $(94.2 \%)$, monkey $(97.7 \%)$, chicken $(91.7 \%)$ and zebrafish $(85.2 \%)$.

For functional domains, porcine SIM1 had high identity with nucleotide sequence of zebrafish in basic, HLH, PAS1 and PAS2 regions (92, 97, 95 and 98\%, separately) while completely conserved sequences were observed in the four functional domains within porcine SIM1 and the other 7 species.

The amino acid sequence of porcine SIM1 showed high homologous to that of human and cattle (98.04 and $98.30 \%$, respectively). A phylogenetic tree based on alignments of full-length amino acid sequence from nine species showed that the ortholog of porcine SIM1 is related to cattle counterpart and mammalian SIM1 are closely related to chicken SIM1 and zebrafish SIM1 (Fig. 2).
Detection of SNP: Alignment between Jinhua and Pietrain cDNA sequence revealed three potential Single Nucleotide Polymorphisms (SNPs). The first substitution located at position $534(\mathrm{c}+534 \mathrm{~T}>\mathrm{C})$ relative to the start codon, the second substitution located at position 990 $(\mathrm{c}+990 \mathrm{C}>\mathrm{T})$ and the third one at position $1677(\mathrm{c}+1677$ $\mathrm{C}>\mathrm{T}$ ). All of the three SNPs were silent mutations. The $\mathrm{c}+534 \mathrm{~T}>\mathrm{C}$ and $\mathrm{c}+1677 \mathrm{C}>\mathrm{T}$ substitutions were novel SNPs, while the $\mathrm{c}+990 \mathrm{C}>\mathrm{T}$ was previously published by Zhao et al. (2008). The c+990 C>T substitution was excluded from genotype and association analysis in the present study as its research had been done in the same population by Zhao et al. (2008). Using PCR-SSCP and sequencing technology, two novel SNPs were genotyped in $\mathrm{PJF} 2$ population.

Association analysis: The association analysis between SNPs and recorded traits revealed that the SIM1 gene had significant effect on carcass composition and meat quality. The substitution of $\mathrm{c}+534 \mathrm{~T}>\mathrm{C}$ showed a extremely significant effect on average backfat thickness, intramuscular fat content, intramuscular water content and ham lean weight $(\mathrm{p}<0.01)$ furthermore, it was significantly associated with ham fat weight $(\mathrm{p}<0.05)$. Allele $\mathrm{T}$ in this site was associated with higher fat proportion and lower ham lean production (Table 2). The substitution of c. $+1677 \mathrm{C}>\mathrm{T}$ had extremely significant effect on average backfat thickness, ham temperature and ham fat weight $(p<0.01$ ), significant effect was observed on loin eye area, ham $\mathrm{pH}$ and ham lean weight $(\mathrm{p}<0.05)$. Allele $\mathrm{T}$ in this site significantly decrease fat content but increase ham temperature, ham lean weight and loin eye area (Table 3). Both of the two SNPs have significant effect on average backfat thickness, ham fat weight and ham lean weight.

In the present study, we cloned and characterized the full cDNA length of porcine SIM1 gene. Alignment analysis indicated that the SIM1 gene has high homology to other species, especially in functional domains. The phylogenetic tree displayed that the porcine SIM1 protein has closely evolutionary relationship with mammals, the ortholog of porcine SIM1 gene is related to its cattle counterpart. Therefore, cloning of porcine SIM1 gene could enrich SIM1 family and afford suitable model for SIM1-related human disease. In human and mouse, SIM1 gene expressed in the central nervous system as well as in other limited tissues such as kidney, lung and skeletal muscle (Chen et al., 1995; Ema et al., 1996). However in the present study, we found that the porcine SIM1 gene had a wide distribution in vivo and expressed in 10 different tissues. Taking into account the previous studies focused on embryos but the study chose adult tissues as template thus, we speculated that SIM1 has 
Table 2: Association analysis between $\mathrm{c}+534 \mathrm{C}>\mathrm{T}$ genotypes and recorded traits Genotypes (Least square means \pm standard deviation)

\begin{tabular}{lcccc} 
Traits & $\mathrm{CC}(\mathrm{n}=83)$ & $\mathrm{CT}(\mathrm{n}=118)$ & $\mathrm{TT}(\mathrm{n}=105)$ & $\mathrm{p}$ value \\
\hline Average backfat thickness $(\mathrm{cm})$ & $2.830 \pm 0.058^{\mathrm{B}}$ & $2.996 \pm 0.049^{\mathrm{B}}$ & $3.221 \pm 0.050^{\mathrm{A}}$ & 0.000 \\
Intramuscular fat content $(\%)$ & $2.346 \pm 0.152^{\mathrm{B}}$ & $2.686 \pm 0.126^{\mathrm{B}}$ & $3.256 \pm 0.125^{\mathrm{A}}$ & 0.000 \\
Intramuscular protein content (\%) & $24.244 \pm 0.123$ & $24.238 \pm 0.105$ & $24.153 \pm 0.101$ & 0.779 \\
Intramuscular water content (\%) & $73.688 \pm 0.178^{\mathrm{a}}$ & $73.403 \pm 0.152^{\mathrm{a}}$ & $72.872 \pm 0.146^{\mathrm{b}}$ & 0.001 \\
Water holding capacity & $0.407 \pm 0.013$ & $0.413 \pm 0.011$ & $0.440 \pm 0.011$ & 0.104 \\
Loin eye area $\left(\mathrm{cm}^{2}\right)$ & $33.263 \pm 0.743$ & $32.637 \pm 0.567$ & $31.543 \pm 0.645$ & 0.216 \\
Ham temperature $\left({ }^{\circ} \mathrm{C}\right)$ & $39.339 \pm 0.150$ & $39.267 \pm 0.126$ & $39.301 \pm 0.129$ & 0.928 \\
Ham pH & $6.340 \pm 0.039$ & $6.347 \pm 0.033$ & $6.372 \pm 0.033$ & 0.782 \\
Ham fat weight $(\mathrm{kg})$ & $1.912 \pm 0.037^{\mathrm{b}}$ & $1.967 \pm 0.032$ & $2.036 \pm 0.032^{\mathrm{a}}$ & 0.043 \\
Ham lean weight $(\mathrm{kg})$ & $5.726 \pm 0.056^{\mathrm{Aa}}$ & $5.618 \pm 0.047^{\mathrm{a}}$ & $5.482 \pm 0.049^{\mathrm{Bb}}$ & 0.004 \\
\hline
\end{tabular}

LSM with superscripts $a$ and $b$ are different at $p<0.05 ; A$ and $B$ at $p<0.01$

Table 3: Association analysis between $\mathrm{c}+1677 \mathrm{~T}>\mathrm{C}$ genotypes and recorded traits

\begin{tabular}{|c|c|c|c|c|}
\hline \multirow[b]{2}{*}{ Traits } & \multicolumn{3}{|c|}{ Genotypes (Least square means \pm standard deviation) } & \multirow[b]{2}{*}{$\mathrm{p}$ value } \\
\hline & $\mathrm{CC}(\mathrm{n}=103)$ & $\mathrm{CT}(\mathrm{n}=141)$ & $\mathrm{TT}(\mathrm{n}=62)$ & \\
\hline Average backfat thickness $(\mathrm{cm})$ & $3.145 \pm 0.052^{\mathrm{a}}$ & $3.032 \pm 0.045^{\mathrm{a}}$ & $2.848 \pm 0.065^{b}$ & 0.001 \\
\hline Intramuscular fat content $(\%)$ & $2.694 \pm 0.136$ & $2.908 \pm 0.117$ & $2.819 \pm 0.174$ & 0.454 \\
\hline Intramuscular protein content (\%) & $24.337 \pm 0.107$ & $24.103 \pm 0.093$ & $24.226 \pm 0.135$ & 0.219 \\
\hline Intramuscular water content (\%) & $73.143 \pm 0.159$ & $73.315 \pm 0.139$ & $73.374 \pm 0.202$ & 0.572 \\
\hline Water holding capacity & $0.424 \pm 0.110$ & $0.424 \pm 0.100$ & $0.407 \pm 0.015$ & 0.560 \\
\hline Loin eye area $\left(\mathrm{cm}^{2}\right)$ & $31.163 \pm 0.607^{b}$ & $33.076 \pm 0.514^{a}$ & $33.379 \pm 0.855^{a}$ & 0.030 \\
\hline Ham temperature $\left({ }^{\circ} \mathrm{C}\right)$ & $39.231 \pm 0.132$ & $39.255 \pm 0.114$ & $39.514 \pm 0.166$ & 0.008 \\
\hline Ham pH & $6.324 \pm 0.034$ & $6.399 \pm 0.029^{a}$ & $6.300 \pm 0.043^{b}$ & 0.075 \\
\hline Ham fat weight $(\mathrm{kg})$ & $2.052 \pm 0.033^{\mathrm{a}}$ & $1.982 \pm 0.028^{\mathrm{a}}$ & $1.839 \pm 0.042^{b}$ & 0.000 \\
\hline Ham lean weight $(\mathrm{kg})$ & $5.505 \pm 0.050^{b}$ & $5.611 \pm 0.043$ & $5.728 \pm 0.064^{\mathrm{a}}$ & 0.016 \\
\hline
\end{tabular}

temporal and spatial differences in gene expression. In human, Traurig et al. (2009) had identified 46 mutations in genomic DNA by sequencing and found a noncoding variant showing strong association with Body Mass Index (BMI) in Pima Indians. Although, none of the common SNP -IVS4+83GA, P352T, T361I, A371 V, A665Hhad significant association with BMI in different population (Ahituv et al., 2007; Traurig et al., 2009). The haplotype reconstructed of $\mathrm{P} 352 \mathrm{~T}$ and $\mathrm{A} 371 \mathrm{~V}$ was modestly associated with BMI in Caucasian males (Hung et al., 2007).

Overexpression of SIM1 in agouti yellow $\left(\mathrm{A}^{\mathrm{y}}\right)$ mice inhibited hyperphagia and reduced fat mass in the $\mathrm{A}^{\mathrm{y}} / \mathrm{SIM} 1$ transgenic mice (Kublaoui et al., 2006), SIM1 ${ }^{-/}$ and $\mathrm{SIM1}^{+/}$mice developed severely obese with increased food intake and a remarkable decrease in hypothalamic Oxytocin (Oxt) and melanocortin 4 receptor (Mc4r) mRNA (Tolson et al., 2010). The SIM1 ${ }^{+/}$mice, however do not show decreased energy expenditure (Michaud et al., 2001 ). Based on these finding, it was proposed that SIM1 gene may involved in the leptin-melanocortin-oxytocin pathway for hyperphagic obesity (Traurig et al., 2009; Tolson et al., 2010).

The two SNPs in the present study do not change primary structure of SIM1 gene, but consecutive evidence demonstrated that synonymous mutation could affect SIM1 function by altering mRNA stem-loop structure or stability (Duan et al., 2003; Capon et al., 2004;
Chamary and Hurst, 2005). In addition, SIM1 gene was assigned at pig chromosome 1 p13 (Zhao et al., 2008), this chromosome overlaps with several QTL affecting backfat thickness and total fat weight (Nezer et al., 2002; Geldermann et al., 2003).

The SIM1 protein contains four functional domains, including the basic, HLH and PAS (1 and 2) regions (Huang et al., 1993; Yamaki et al., 1996). The basic region mediate DNA binding while the $\mathrm{HLH}$ and PAS domains together direct the formation of protein dimmers and contributes to the stabilization of the DNA binding conformation (Huang et al., 1993; Erbel et al., 2003). In the present study, completely conserved sequences in SIM1 functional domains were observed among all species except zebrafish, this result was consistent with previous studies (Ema et al., 1996; Eaton and Glasgow, 2006). The similarity in nucleotide sequence represents a high potential for binding the same DNA sequence in vivo (Woods and Whitelaw, 2002) thus, it was expected that SIM1 proteins had conserved function within different species.

In relation to carcass traits, the average backfat thickness, ham fat weight, ham lean weight were significantly affected by both SNPs and loin eye area was significantly affected by $\mathrm{T} 1677 \mathrm{C}$ substitution. Regarding the meat quality traits, intramuscular water content, ham temperature and ham $\mathrm{pH}$ were significantly affected by C534T and T1677C, separately. 


\section{CONCLUSION}

In this study, SIM1 gene had significant effect on porcine carcass composition and meat quality. SIM1 gene is a candidate gene for economic traits. This result correspond with earlier inference (Zhao et al., 2008).

However, the association observed may arise from linkage disequilibrium within other regions of SIM1 gene or causative substitution in neighbouring locus. Thus, further studies should be carried out in different populations and using larger population size to demonstrate the real impact of the SIM1 gene on carcass and meat quality traits.

\section{ACKNOWLEDGEMENTS}

This research was supported by the National High Technology Research and Development Program of China (863 program, no. 2007AA10Z158) and the National Major Basic Research Program of China (973 Program, no. 2006CB102100)

\section{REFERENCES}

Ahituv, N., N. Kavaslar, W. Schackwitz, A. Ustaszewska and J. Martin et al., 2007. Medical sequencing at the extremes of human body mass. Am. J. Hum. Genet, 80: 779-791.

Capon, F., M.H. Allen, M. Ameen, A.D. Burden, D. Tillman, J.N. Barkerand and R.C. Trembath, 2004. A synonymous SNP of the corneodesmosin gene leads to increased mRNA stability and demonstrates association with psoriasis across diverse ethnic groups. Human Mol. Genet., 13: 2361-2368.

Chamary, J.V. and L.D. Hurst, 2005. Evidence for selection on synonymous mutations affecting stability of mRNA secondary structure in mammals. Genome. Biol., 6: R75-R75.

Chen, H., R. Chrast, C. Rossier, A. Gos and S.E. Antonarakisis et al., 1995. Single-minded and downs syndrome. Nat. Genet., 10: 9-10.

Duan, J., M.S. Wainwright, J.M. Comeron, N. Saitou, A.R. Sanders, J. Gelernter and P.V. Gejman, 2003. Synonymous mutations in the human Dopamine receptor D2 (DRD2) affect $\mathrm{mRNA}$ stability and synthesis of the receptor. Hum. Mol. Genet, 12: $205-216$.

Eaton, J.L. and E. Glasgow, 2006. The zebrafish bHLHPAS transcriptional regulator, single-minded 1 (SIM1), is required for isotocin cell development. Dev. Dynam., 235: 2071-2082.
Ema, M., M. Suzuki, M. Morita, K. Hirose and $\mathrm{K}$. Sogawa et al., 1996. CDNA cloning of a murine homologue of Drosophila single-minded, its mRNA expression in mouse development and chromosome localization. Biochem. Biophys. Res. Commun., 218: 588-594.

Erbel, P.J., P.B. Card, O. Karakuzu, R.K. Bruick and K.H. Gardner, 2003. Structural basis for PAS domain heterodimerization in the basic helix-loop-helix-PAS transcription factor hypoxia-inducible factor. Proc. Natl. Acad. Sci. USA., 100: 15504-15509.

Geldermann, H., E. Muller, G. Moser, G. Reiner and H. Bartenschlager et al., 2003. Genome wide linkage and QTL mapping in porcine F2 families generated from Pietrain, Meishan and Wild Boar crosses. J. Anim. Breed. Genet., 120: 363-393.

Gilhuis, H.J., C.M. van Ravenswaaij, B.J. Hamel and F.J. Gabreels, 2000. Interstitial $6 \mathrm{q}$ deletion with a prader-willi-like phenotype: A new case and review of the literature. Eur. J. Paediatr. Neurol., 4: 39-43.

Holder, J.L., L. Jr. Zhang, B.M. Kublaoui, R.J. DiLeone and O.K. Oz et al., 2004. SIM1 gene dosage modulates the homeostatic feeding response to increased dietary fat in mice. Am. J. Physiol. Endocrinol. Metab., 287: E105-E113.

Hollander, E., S. Novotny, M. Hanratty, R. Yaffe, C.M. DeCaria, B.R. Aronowritz and S. Mosovich, 2003. Oxytocin infusion reduces repetitive behaviors in adults with autistic and aspergers disorders. Neuropsychopharmacology, 28: 193-198.

Huang, Z.J., I. Edery and M. Rosbash, 1993. PAS is a dimerization domain common to Drosophila period and several transcription factors. Nature, 364: 259-262.

Hung, C.C., J. Luan, M. Sims, J.M. Keogh and C. Hall et al., 2007. Studies of the SIM1 gene in relation to human obesity and obesity-related traits. Int. J. Obes., 31: 429-434.

Insel, T.R., D.J. O'Brien and J.F. Leckman, 1999. Oxytocin, vasopressin and autism: Is there a connection. Biol. Psychiatry, 45: 145-157.

Kobayashi, E., H. Hasebe, K. Kuchida, T. Kawamura, T. Okumura and T. Abe, 2009. Detection of DNA polymorphisms in the MSTN gene and the effect of F94L on meat quantity and quality traits in Japanese black x limousin F2 population. J. Anim. Vet. Adv., 8: 1609-1615.

Kublaoui, B.M., J.L. Jr. Holder, K.P. Tolson, T. Gemelli and A.R. Zinn, 2006. SIM1 overexpression partially rescues agouti yellow and diet-induced obesity by normalizing food intake. Endocrinology, 147: 4542-4549. 
Kumar, S., K. Tamura and M. Nei, 2004. MEGA3: Integrated software for molecular evolutionary genetics analysis and sequence alignment. Brief. Bioinform., 5: 150-163.

Liu, Y., X. Lu, Y.R. Luo, J.P. Zhou, X.Y. Liu, Q. Zhang and Z.J. Yin, 2009. Effect of single nucleotide polymorphism of IRF1 gene on cytokine traits in three pig breeds. J. Anim. Vet. Adv., 18: 2346-2350.

Michaud, J.L., F. Boucher, A. Melnyk, F. Gauthier and E. Goshu et al., 2001. SIM1 haploinsufficiency causes hyperphagia, obesity and reduction of the paraventricular nucleus of the hypothalamus. Hum. Mol. Genet., 10: 1465-1473.

Michuad, J.L., T. Rosenquist, N.R. May and C.M. Fan, 1998. Development of neuroendocrine lineages requires the bHLH-PAS transcription factor SIM1. Genes. Dev., 12: 3264-3275.

Nezer, C., L. Moreau, D. Wagenaar and M. Georges, 2002. Results of a whole genome scan targeting QTL for growth and carcass traits in a Pietrain $\times$ Large White intercross. Genet. Sel. Evol., 34: 371-387.

Swaab, D.F., J.S. Purba and M.A. Hofman, 1995. Alterations in the hypothalamic paraventricular nucleus and its oxytocin neurons (putative satiety cells) in Prader-Willi Syndrome: A study of ?ve cases. J. Clin. Endocrinol. Metab., 80: 573-579.

Tolson, K.P., T. Gemelli, L. Gautron, J.K. Elmquist, A.R. Zinn and B.M. Kublaoui, 2010. Postnatal SIM1 deficiency cause hyperphagic obesity and reduced $\mathrm{Mc} 4 \mathrm{r}$ and Oxytocin expression. J. Neurosci., 30: 3803-3812.
Traurig, M., J. Mack, R.L. Hanson, M. Ghoussaini and D. Meyre et al., 2009. Common variation in SIM1 is reproducibly associated with BMI in Pima Indians. Diabetes, 58: 1682-1689.

Varela, M.C., A.Y. Simooes-Sato, C.A. Kim, D.R. Bertola, C.I. de Castro and C.P. Koiffman, 2006. A new case of interstitial $6 q 16.2$ deletion in a patient with praderwilli-like phenotype and investigation of SIMI gene deletion in 87 patients with syndromic obesity. Eur. J. Med. Genet., 49: 298-305.

Visscher, P., R. Pong-Wong, C. Whittemore and C. Haley, 2000. Impact of biotechnology on (cross) breeding programmes in pigs. Livest. Prod. Sci., 65: 57-70.

Woods, S.L. and M.L. Whitelaw, 2002. Differential activities of murine single minded 1 (SIMI) and SIM2 on a hypoxic response element. Cross-talk between basic helix-loop-helix/per-Arnt-Sim homology transcription factors. J. Biol. Chem., 277: 10236-10243.

Yamaki, A., S. Noda, J. Kudoh, N. Shindoh and H. Maeda et al., 1996. The mammalian single-minded (SIM) gene: Mouse cDNA structure and diencephalic expression indicate a candidate gene for down syndrome. Genomics, 35: 136-143.

Zhao, X.F., N.Y. Xu, Z. Chen, Q. Wang and X.L. Guo, 2008. Single-minded 1 gene mapping and its variants association with growth, carcass composition and meat quality traits in pig. Asian-Aust. J. Anim., 21: $941-946$. 